\title{
A Very Rare Case: Metastatic Inguinal Mass From Primary Lung Cancer
}

Olgu Sunumu Case Report

\section{Çok Nadir Görülen Bir Olgu: Primeri Akciğer Kanseri Olan Metastatik Inguinal Kitle}

\author{
Mehmet Zeynel Keskin $\odot$, Yusuf Özlem İlbey ๑
}

\begin{abstract}
Tepecik Training and Research Hospital, Department of Urology Cancers of unknown primary (CUP) that we rarely encounter, conversely rank fourth in cancer-related deaths in males and females. In this case, we aimed to present how the primary of an inguinal mass, which could have been diagnosed as CUP in the 80's, could be detected using advanced immunohistochemical methods.
\end{abstract}

Keywords: Metastatic inguinal mass, lung cancer, large cell adenocarcinoma

öz

Nadir olarak karşımıza çıkan primeri bilinmeyen kanser (PBK) olguları literatüre bakıldı̆ında ise zıt bir şekilde erkek ve kadında kansere bağlı ölümlerde 4. sıklıkta yer almaktadır. Bu olgumuzda, 80'li yıllarda PBK teşhisi konulabilecek inguinal kitlenin, gelişen immünohistokimyasal yöntemler sayesinde primerinin belirlenmesinin nasıl olası olabileceğini sunmayı amaçladık.

Anahtar kelimeler: Metastatik inguinal kitle, akciğer kanseri, büyük hücreli akciğer kanseri

\section{INTRODUCTION}

A mass of unknown primary is a health problem that all clinicians encounter in their lives and they subject these patients to multiple laboratory, immunohistochemical analyzes, and imaging methods to reach a definitive diagnosis with a higher financial burden. While $15 \%$ of all cases of cancer were diagnosed as cancers of unknown primary (CUP) in the 80 's, this rate regressed to levels of $2.3-4.2 \%$ in the 2000 s, particularly due to advances in imaging methods and pathological evaluations ${ }^{(1,2)}$. Although cases of CUP appear to present rarely, they conversely rank fourth in cancer-related deaths in males and females in literature and epidemiologic studies ${ }^{(3)}$. In this case, we aimed to present how the primary of an inguinal mass, which could have been diagnosed as CUP in the 80 's, could be detected using advanced immunohistochemical methods.

\section{CASE}

A 66-year-old male patient who had undergone a lobectomy 6 months prior to his presentation due to a mass in the right lung had a history of referral to our clinic for a swelling that extended from the left scrotum to the inguinal area over a period of two months. Inguinal and scrotal ultrasonography

(USG) 
results revealed that the mass originated from within the scrotum without connection to the testicle and extended up to the inguinal canal. The magnetic resonance imaging (MR) scan performed subsequently demonstrated a $7.5 \mathrm{~cm}$ solid mass localized in the left scrotum with necrotic areas in the center. The mass, which did not have a connection to the testicle, was found to manifest significant diffusion restriction and intense contrast enhancement in the contrast-enhanced scan. Additionally, few bilateral obturator lymph nodes were determined, the largest of which measured $17 \mathrm{~mm}$ on the left side (Figure 1).

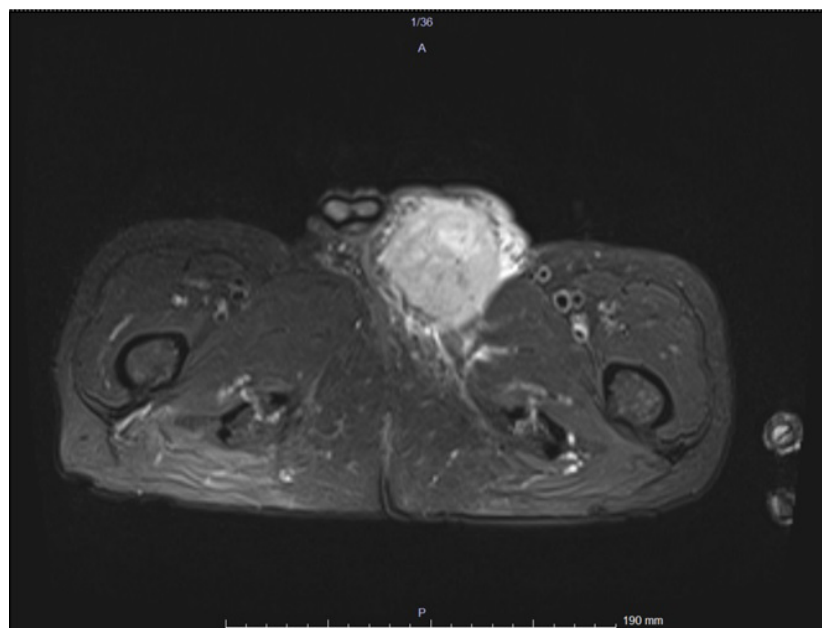

Figure 1.

The mass that appeared to meet malignancy criteria was evaluated by histopathologic examination of a tru-cut biopsy specimen. Tru-cut biopsy results did not establish definitive diagnosis of the primary tumor, and also immunohistochemical analyzes (CK7, CK20, TTF1, p63,CK5/6, napsin) performed produced suboptimal results. We then performed mass excision of the tumoral mass through left inguinal incision for the purpose of excisional biopsy. Macroscopic pathological evaluation of the excision material revealed a $12 \times 8 \times 8 \mathrm{~cm}$ mass of "fish flesh" consistency that was covered by ulcerated skin. Microscopically, there were widespread areas of necrosis on the surgical margin. The tumor, which manifested CK7 positivity and CK5/6 focal positivity, was reported to be a metastatic lesion originating from large-cell lung carcinoma. The patient who did not present additional problems in his follow-up examinations was referred to the medical oncology clinic.

\section{DISCUSSION}

The tumoral mass of our patient, whom we initially considered as a case of CUP, was in fact an advanced case of lung cancer with scrotal/inguinal metastasis based on positive staining with markers used particularly in malignancies of the respiratory system and in gynecology such as CK 7, and conforming clinical findings (history of lung cancer). It has been reported in the literature that the primary of $20 \%$ of CUP patients can be determined while the patient is alive (4). The malignancies determined to be CUP can be sorted based on decreasing prevalence rates as lung, pancreas, gastrointestinal, and gynecologic system cancers ${ }^{(3)}$. Nystrom and colleagues highlighted this issue at the end of the 70's and stressed lung radiography as the initial diagnostic assessment in cases of CUP ${ }^{(5)}$. However, when we consider the issue more specifically and focus on inguinal masses of unknown primary (IMUP), the primary cancers that are encountered most frequently include; lymphomas, anaplastic carcinomas, squamous carcinomas, and adenocarcinomas. Therefore anorectal, gynecological, and urological (cystoscopic) examinations are absolutely necessary in cases of IMUP. Lung cancers are encountered in only $1-3 \%$ of these cases ${ }^{(6-8)}$. Medullary thyroid cancer was reported for the first time in the literature in 2014 as a less prevalent CUP ${ }^{(9)}$. Related systems were inspected in our case as well, but the primary could not be determined. Although known history of lung cancer appears to have facilitated diagnosis, failure to establish definitive diagnosis based on histopathologic examination of tru-cut biopsy specimens attests to the fact that identifying the primary in this patient group is not a very simple process. When we consider that only $1-3.5 \%$ of CUP cases are comprised of inguinal masses, it is clear that identifying the primary for such a case is not 
always possible. In the literature, the recommended treatment for cases of IMUP involves the excision of the mass followed by radiotherapy, and the role of systemic chemotherapy is disputed ${ }^{(10,11)}$. Our case that could not be categorized as CUP/IMUP any more as the primary was determined, was a case of lung cancer that metastasized to the scrotal and inguinal subcutaneous and cutaneous regions, and was referred to the medical oncology clinic where this patient was being followed up.

With regard to our case, considering that cases of CUP constitute roughly $3 \%$ of all cancers, cases of IMUP constitute roughly $3 \%$ of CUP cases, and that $3 \%$ of IMUP cases have the lung as a primary origin, it is clear that such cases may not be diagnosed easily, resulting in long-term and expensive efforts. The purpose for presenting this case was to stress that in similar cases of IMUP, inspecting only the neighboring organs is not sufficient as distant organs such as the lung could -although rarely-present themselves as the primary tumor focus, and to contribute to the literature to shorten painstakingly longer diagnostic process.

\section{Conflict of Interest: None.}

Informed Consent: Receipt.

\section{REFERENCES}

1. Nissenblatt MJ. The CUP syndrome (carcinoma unknown primary). Cancer Treat Rev. 1981;8:211-24. [CrossRef]

2. Muir C. Cancer of unknown primary site. Cancer. 1995;75:353-6. [CrossRef]

3. Pavlidis, N. Cancer of unknown primary: biological and clinicalcharacteristics. Annals of oncology.2003;14(suppl_3):iii11iii8. [CrossRef]

4. Pavlidis N, Briasoulis E, Hainsworth J, Greco FA. Diagnostic and therapeutic management of cancer of an unknown primary. European journal of cancer. 2003;39(14):1990-2005. [CrossRef]

5. Nystrom S, Weiner J, Wolf RM, Bateman JR, Viola MV. Identifying the primary site in metastatic cancer of unknown origin. Inadequacy of roentgenographic procedures. JAMA. 1979;241:381-3. [CrossRef]

6. Komeya M, Sahoda T, Sugiura S, Sawada T, Kitami K: A case of metastatic prostate adenocarcinoma to an inguinal lymph node. Central Eur J Urol. 2012;65:96-7. [CrossRef]

7. Ismail M, Zaman F, Baithun S, Nargund V, Pati J, Masood J: Inguinal lymph node metastases from a testicular seminoma: a case report and a review of the literature. J Med Case Rep. 2010;4:378. [CrossRef]

8. Bobba RK, Doll DC, Perry MC, Odem JL. Skin metastases in non-small cell lung cancer. The American journal of the medical sciences. 2012;344(1):59-62. [CrossRef]

9. Appetecchia M, Barnabei A, Pompeo V, et al. Testicular and inguinal lymph node metastases of medullary thyroid cancer: a case report and review of the literature. BMC endocrine disorders. 2014;14(1):84. [CrossRef]

10. Greco FA, Hainsworth JD. Cancer of unknown primary site. In DeVita TV, Hellman S, Rosenberg SA (eds): Cancer: Principles and Practice of Oncology, fourth edition. Philadelphia, PA: J.B. Lippincott. 1997; 2423-43.

11. Holmes FF, Fouts TL. Metastatic cancer of unknown primary site. Cancer. 1970;26:816-20. [CrossRef] 